\title{
UJI FARMAKOLOGI SEDIAAN PLESTER PATCH DARI LIMBAH KULIT PISANG KEPOK (MUSA ACUMINATA) UNTUK PENYEMBUHAN LUKA BAKAR
}

\author{
Syamsuri Syakri ${ }^{1}$
}

\author{
1Universitas Islam Negeri Alauddin Makassar
}

Email: surisweet86@yahoo.com

DOI: $\underline{10.24252 / \text { kesehatan.v12i1.7395 }}$

\begin{abstract}
Abstrak
Telah dilakukan penelitian mengenai Uji Farmakologi Sediaan Patch Dari Limbah Kulit Pisang Kepok Untuk Penyembuhan Luka Bakar. Penggunaan kulit pisang kepok yang belum matang untuk membantu mempercepat durasi penyembuhan luka sudah pernah dilakukan, namun pada peneltiain terdahulu, kulit pisang kepok diekstraksi, melainkan dibuat dalam bentuk gel, sedangkan dalam sediaan plester patch belum pernah diteliti sebelumnya. Tujuan penelitian ini untuk membuat sediaan plester patch yang memiliki efektivitas paling baik dalam menyembuhkan luka, serta pembuatan plester patch ini untuk memberikan suatu kenyamanan dan kemudahan kepada konsumen dalam mengobati luka. Penelitian ini menggunakan metode kuantitatif dengan cara metode eksperimental laboratorium, cara kerjanya berupa pengambilan sampel, ekstraksi kulit buah pisang kepok, membuat plester patch dengan menggunakan bahan aktif ekstrak kulit pisang kepok (Musa acuminate), dan bahan tambahan lainnya berupa Gliserin, kitosan, HPMC, Tween 80, kemudian diformulasikan menjadi 3 macam formula, selanjutnya membandingkan dengan kontrol positif dan negatif, evaluasi plester patch, dan setelah pengujian daya sembuh luka pada hewan kelinci. Dari hasil penelitian didapatkan Formula III yang memiliki efektifitas paling baik dalam menyembuhkan luka yaitu konsentrasi $30 \%$ kulit buah pisang kepok.
\end{abstract}

\section{Kata kunci : Formulasi; Plester Patch; Luka Bakar}

\begin{abstract}
Research has been conducted on the Pharmacological Test of Patches Preparation from Kepok Banana Skin Waste to Heal Burns. The use of immature kepok banana peels to help speed up the duration of wound healing has already been done, but in previous studies, kepok banana peel was extracted, but made in gel form, whereas in patch plaster preparations had never been studied before. The purpose of this research is to make patch plaster preparations that have the best effectiveness in healing wounds, as well as making patch plasters to provide comfort and convenience to consumers in treating wounds. This research uses a quantitative method by means of laboratory experimental methods, how it works in the form of sampling, extraction of kepok banana peel, making patch plaster using active ingredients kepok banana peel extract (Musa acuminate), and other additives in the form of glycerin, chitosan, HPMC, Tween 80, then formulated into 3 types of formulas, then compared with positive and negative controls, evaluation of patch patches and after testing the healing power of wounds in rabbit animals. From the results of the study it was found that Formula III had the best effectiveness in healing wounds, namely the concentration of $30 \%$ kepok banana peels.
\end{abstract}

Keywords: Formulation; Plaster Patch; Burns 


\section{PENDAHULUAN}

Proses penyembuhan luka adalah proses yang rumit dan telah menjadi bahan penelitian oleh para ahli selama lebih dari satu abad. Secara konvensional tahap penyembuhan luka dibagi dalam empat tahap, yaitu tahap eksudatif, resoprtif, proliferatif, dan regeneratif. Berdasarkan aspek imunologi dibagi dalam tiga tahap, yakni tahap inflamasi, proliferatif, dan modulasi. Semenjak perbedaan fase memberikan konsekuensi dalam perawatan luka, tahap konvensional harus diutamakan karena alasan kepraktisan.

Buah pisang kepok mengandung karbohidrat, kalsium, fosfor, vitamin A, B dan C. Beberapa senyawa metabolit sekunder yang dapat digunakan sebagai obat untuk radang tonsil dan kurang darah juga dapat ditemukan pada pisang ini (Atun, dkk, 2007: 83). Selain buah pisang kepok (Musa paradisiaca L), kulit buah pisang kepok juga mengandung komponen biokimia berupa selulosa, hemiselulosa, pigmen klorofil serta zat pektin yang mengandung asam galacturonic, arabinosa, galaktosa. Kandungan komponen biokimia kulit buah pisang kepok ini diketahui dapat digunakan untuk menyerap logam-logam berat (Abdi, dkk, 2015: 910). Kulit buah pisang kepok juga mengandung senyawa metabolit sekunder jenis flavonoid 5 , 6, 7, 4'-tetrahidroksi-3-4-flavan-diol (Atun, dkk, 2007: 87). Penelitian lain yang dilakukan oleh (Supriyanti, dkk, 2015: 397), menunjukkan bahwa kulit buah pisang kepok juga memiliki beberapa kandungan metabolit lain seperti terpenoid dan tanin.

Selama ini, setelah memakan daging buah pisang kepok, kulit pisang segera dibuang karena dianggap sebagai barang yang tidak berguna atau memiliki manfaat. Kulit pisang yang kita anggap sebagai limbah ternyata memiliki banyak manfaat, salah satunya dapat digunakan untuk mempercepat penyembuhan luka. Akan tetapi, penggunaan kulit pisang sebagai bahan untul mempercepat proses penyembuhan luka masih belum banyak didokumentasikan. Penggunaan kulit pisang kepok yang belum matang untuk membantu mempercepat durasi penyembuhan luka sudah pernah dilakukan, namun pada penelitian terdahulu, kulit pisang kepok diekstraksi, melainkan dibuat dalam bentuk gel.

Pengobatan luka selama ini hanya berasal dari obat sintetis, seperti obat merah, boorwater, dan bubuk sulfa, akan tetapi obat-obat luka tersebut menimbulkan efek samping yang berbahaya, seperti toksik terhadap otak dan syaraf, serta reaksi hipersensitifitas terhadap kulit. Pengobatan luka mrnggunakan antiseptik juga tidak dibenarkan karena menimbulkan hipertiroid.

Berdasarkan uraian diatas perlu dilakukan penelitian yang bertujuan memberikan suatu inovasi terbaru untuk pengobatan luka dari limbah pisang kepok dalam bentuk sediaan plester patch.

\section{METODOLOGI PENELITIAN}

Penelitian ini menggunakan metode kuantitatif, dengan menggunakan pendekatan penelitian eksperimental laboratorium. Prosedur Pembuatan Patch yaitu Larutan polimer kitosan dibuat dengan menggunakan $1 \%$ asam asetat (A), Polimer HPMC dibuat dengan campuran aquadest : etanol (8:2). Kemudian Lautan A dicampurkan dengan larutan B, dihomogenkan (C) dengan menggunakan magnetic stirrer pada $350 \mathrm{rpm}$. Pada larutan tersebut 
ditambahkan tween 80. Kemudian Ekstrak Kulit buah pisang kepok dicampurkan selama 30 menit. Selanjutnya ditambahkan $20 \%$ b/b dari gliserin sebagai plasticizer dengan pengadukan konstan. Berikut ini Tabel rancangan Formulasi Plester (Patch) Kulit pisang kepok :

Tabel 1. (Formula Sediaan Plester Patch Kulit Limbah Kulit Pisang Kepok)

\begin{tabular}{llllll}
\hline Kode Formula & Plstizier & \multicolumn{2}{l}{ Perbandingan Polimer } & Enhancer & $\begin{array}{l}\text { Ekstrak } \\
\text { Kulit Pisang } \\
\end{array}$ \\
& Gliserin & Kitosan & HPMC & Tween 80 & Kepok \\
\hline Kontrol & $20 \%$ & $100 \mathrm{mg}$ & $100 \mathrm{mg}$ & $3 \%$ & - \\
\hline FI & $20 \%$ & $100 \mathrm{mg}$ & $100 \mathrm{mg}$ & $3 \%$ & $10 \%$ \\
\hline FII & $20 \%$ & $100 \mathrm{mg}$ & $100 \mathrm{mg}$ & $3 \%$ & $20 \%$ \\
\hline FIII & $20 \%$ & $100 \mathrm{mg}$ & $100 \mathrm{mg}$ & $3 \%$ & $30 \%$ \\
\hline
\end{tabular}

Bobot Per Patch $500 \mathrm{mg}$

\section{HASIL DAN PEMBAHASAN}

Kandungan flavonoid merupakan antioksidan kuat yang dapat mengurangi lipid peroksida, meningkatkan kecepatan epitelisasi dan bersifat antimikroba. Penurunan lipid peroksidasi oleh flavonoid akan meningkatkan viabilitas serabut kolagen. Tanin bersifat antimikroba dan meningkatkan epitelisasi, sedangkan saponin meningkatkan kemampuan reseptor TGF- $\beta$ fibroblas berkaitan dengan faktor pertumbuhan yang diperlukan oleh fibroblas dalam mensintesis kolagen. Adanya kandungan flavonoid, tanin, dan saponin yang terkandung pada ekstrak kulit buah pisang kepok tersebut diketahui dapat mempercepat proses penyembuhan luka.

Pengujian efek penyembuhan luka dari ekstrak kulit buah pisang kepok diujikan pada punggung kelinci yang diberikan luka sayatan dengan panjang luka $3 \mathrm{~cm}$ dan kedalaman luka menembus lapisan dermis sekitar $2 \mathrm{~mm}$ dari permukaan kulit. Pengamatan penelitian dilakukan dengan mengukur perubahan panjang pada kelinci. Interval waktu pengukuran setiap 1×24 jam dan dilanjutkan dengan menempelkan plester patch pada punggung kelinci yang luka. Pengamatan dilakukan hingga luka tertutup sempurna.

Dari hasil pengamatan yang dilakukan, diketahui ketiga formula ini memberikan efek penutupan luka yang berbda-beda. Pada formula 1, luka sayatan dapat sembuh selama 16 hari, untuk formula 2 luka sayatan dapat sembuh selama15 hari, dan formula 3 dapat sembuh selama 13 hari.

Tabel 2 (Pengukuran Luka Sayat Pada Kelinci)

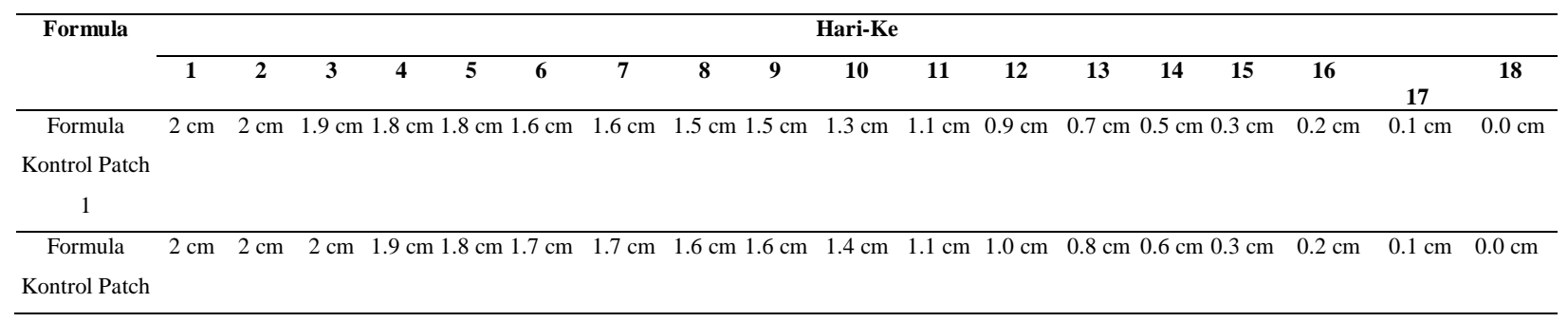




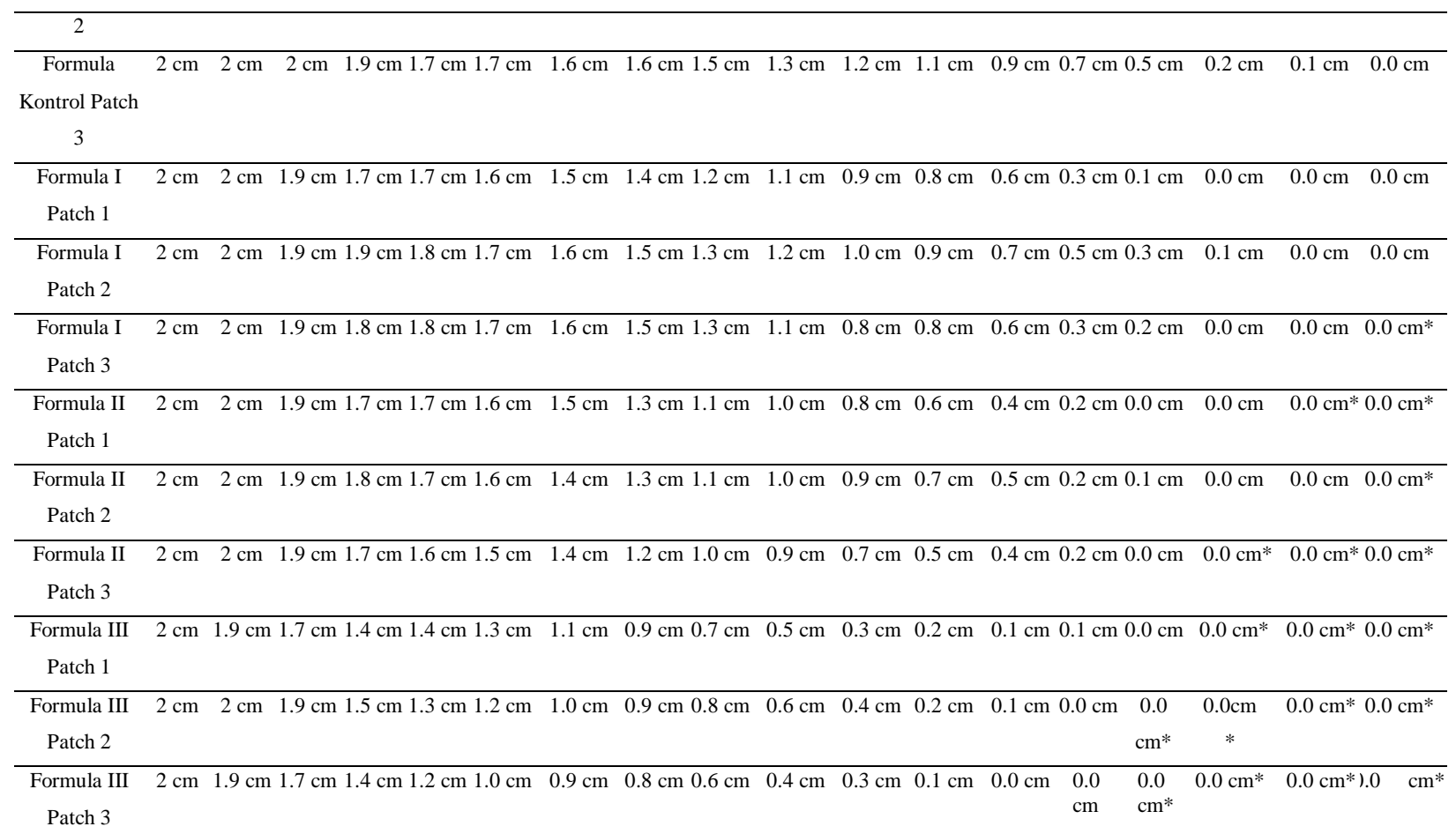

\section{KESIMPULAN}

1. Formula III memiliki efektifitas paling baik dalam evaluasi Plester Patch yaitu berdasarkan pengujian diameter dengan rata-rata $43,66 \mathrm{~mm}$, pengujian lipatan kelunturan patch sebanyak 333 lipatan, persentase penyerapan air sebesar 49,2\%

2. Konsentrasi $30 \%$ kulit buah pisang kepok yang paling baik dalam menyembuhkan luka pada kulit

3. Sediaan Plester Patch dari kulit pisang kepok untuk formula,1,2, dan 3 dapat menyembuhkan luka, tetapi yang paling optimal dan cepat dalam menyembuhkan luka yaitu pada formula 3 selama 13 hari.

\section{DAFTAR PUSTAKA}

Atun, Sri, dkk. (2017). Identifikasi dan Uji Aktivitas Antioksidan Senyawa Kimia dari Ekstrak Metanol Kulit Buah Pisang (Musa paradisiaca L). Departement OfChemistry Education, Faulti Of Mathematics and Natural SciencesYogyakarta.

Chen, L. Arbieva ZH. Guo S. Marucha PT, Mustoe TA, DiPietro LA. (2010) Potisional differences in the wound transcriptome of skin and oral mucosa. BMC genomic. 11: 471

Cohen, I.K, Diegelmann RF, Yager DR, Wornum IL, Graham M, Crossland MC. (1999). Wound care and wound healing: Schwartz SI, Spencer S, Fischer D, Galloway DF, of surgery. Edisi ke-7. New York: McGraw-Hill

Bastone, E.B. Freer. TJ. (2000). McNamara. JR. Epidemiology of dental trauma: A Review of the Literature. Aust Dent J; 45(1): 2-5.

Smeltzer, S. Bare BG. (2002). Buku Ajar Keperawatan Medikal Bedah Brunner \& Suddarth edisi 8 volume 1. Jakarta: Penerbit Buku Kedokteran.

Supriyanti, F M. T, dkk. (2015). Pemanfaatan Ekstrak Kulit Pisang Kepok (Musa Bluggoe) 
Sebagai Sumber Antioksidan pada Produksi Tahu. Makalah Pendamping Biokimia, Departemen Pendidikan Kimia, FPMIPA Bandung.

Hasniar. (2018). Pengaruh Variasi Konsentrasi Ekstrak Etanol Kulit Buah Pisang Kepok (Musa paradisiaca) Dalam Bentuk Sediaan Gel Menggunakan Basis HPMC Terhadap Penyembuhan Luka Sayat Pada kelinci (Oryctolagus cuniculus). Fakultas Kedokteran dan Ilmu Kesehatan, UIN Alauddin Makassar

Rupina, W. (2016). “Efek Salep Ekstrak Etanol 70\% Daun Karamunting Terhadap Reepitelisasi Luka Insisi Kulit Tikus Wistar". FK Tanjungpura.

Thakur,R. (2011) "Prastices In Wound Healing Studies Of Plants". Evid Based Complement Alternat Med.

Ningsi, S. (2015). Formulasi, Karakterisasi dan Uji Penetrasi In Vitro Patch Ekstrak Biji Kopi Robusta (Coffea canephora) Sebagai Sediaan Anti Selulit. JIF FIK UINAM, 2 (3) 